\title{
An Analysis of the Impact of Strategic Marketing on Profitability of Rural Banks - A Case Study of Dangme Bank
}

\author{
George K. Amoako (Corresponding author) \\ Marketing Department, Central Business School, Central University College, Miotso Campus \\ PO box 2305, Accra, Ghana \\ E-mail: gako2001us@yahoo.com
}

Kwasi Dartey-Baah

University of Ghana Business School, Accra, Ghana

E-mail: kdartey-baah@ug.edu.gh

Received: January7, 2012 Accepted: February 8, 2012 Published: April 1, 2012

doi:10.5539/ijms.v4n2p150 URL: http://dx.doi.org/10.5539/ijms.v4n2p150

\begin{abstract}
The purpose of this study is to examine the factors that influence strategic marketing in relation to profitability in rural banking in Ghana. The research was conducted to see how management and employees follow strategic marketing programmes in delivering superior quality service to their customers and how customers view the service that they receive from the bank. Data was collected from primary and secondary sources. The research revealed that strategic marketing has an effect on the profitability of rural bank services; it revealed that Dangme Rural Bank was marketing oriented and were practicing strategic marketing very well. All employees and the management were conscious of strategic marketing process and activities.
\end{abstract}

Keywords: Ghana, Rural bank, Strategic marketing, Performance, Dangme

\section{Introduction}

Ghana, like other sub-Saharan countries, has traditionally experienced low productivity, low income levels, low domestic savings, unemployment, and malnutrition. In 1976, the Ghanaian government, through the Bank of Ghana, established Rural Banks to channel credit to productive rural ventures and promote rural development. Rural development is a strategy intended to improve the economic and social life of the rural poor (World Bank 1975). Rural credit has been used in Ghana to enable the poor to weather shocks without selling the productive assets the poor need for protection against future shocks (FAO 1994).

The business environment has become a war zone whereby every company is trying to do something to succeed and remain in business. In view of this has arisen the need to employ strategy in a business to give it a competitive edge in order for it to compete effectively and be a force to reckon with. Strategy is the matching of the activities of an organization to the environment in which it operates and to its own resource capabilities (Johnson Scholes 1988). Marketing is defined as an organizational functional and a set of processes for creating, communicating, and delivering value to customers and for managing customer relationships in ways that benefit the organization and its stakeholders (Kotler 2005). Markets were formally focusing on just selling physical products and neglecting services which are intangible in nature. Service was defined by Kotler and Keller in their book 'Marketing Management Analysis, Planning, Implementation and Control, $8^{\text {th }}$ Edition as any act or performance one party can offer to another party that is essentially intangible and does not result in the ownership of anything, its production may or may not be tied to physical product. The purpose of this write up is to study the banking sector specifically rural bank services in Ghana. In 1976 rural banking was introduced in Ghana and was instituted in Nyarkrom in the central region of Ghana. Rural bank is a body incorporated whose name includes the World Bank and which is licensed by the bank of Ghana to carry on specific banking business. Strategic marketing Management has been perceived as the preserve of big and multinational companies in Ghana and Africa. Rural banks in Ghana have assumed important and strategic role in the economy and hence the need for application of strategic marketing principles. Records from Mix Market Ghana shows that as at the 
end of 2010 Micro finance companies in Ghana of which rural banks form over 58\% had a total of 194,786 borrowers borrowing US\$71.7million and 488,633 depositors also depositing US\$62.0 million(www.mixmarkets.org/mfi/country/ghana accessed 28/11/2011)

Since independence in 1957, the Ghanaian government has made several attempts to promote rural development in an effort to increase the living standard of the people who reside in rural areas (Kudiabor 1974).

According to the Moshi Conference (1969), the purpose of rural development is "a rise in the standard of living and favorable changes in the way of life of the people concerned." However, there is some anecdotal evidence that many beneficiaries of Rural Bank credit are salaried workers, whose likelihood of loan repayment is believed to be better than that of the small-scale rural producer. There is also some evidence that loan recipients use the credit for purposes other than those for which the loans are intended. Much analysis has not been done on the effectiveness or the impact of the Ghanaian Rural Banks on rural farmers. The fundamental aim of rural bank is to help rural communities in banking activities and development project, after a study was conducted into the problems of the rural communities especially farmers in getting credit facilities from commercial banks which were by then in operation and mainly centered in the cities. Farmers were asked to provide collateral securities and also open a current account by these commercial banks as a condition for assessing credit facilities; this made it difficult for farmers to access loans since most of them could not meet these conditions from these commercial banks.

In respect of this problem, a sudy was conducted and the report necessitated the introduction of rural banks. Based on the recommendation from the study, a team from the Bank of Ghana was sent to Philippines to study the operation of their Rural Banking System. The team was sent to Philippines because Bank of Ghana report says Philippines is one of the few countries which successfully operated such a banking system on a fairly large scale. Another reason was that their stage of economic development was similar and relevant to that of Ghana.

After the study in Philippines, a pilot project was set up at Nyarkrom in the Central Region of Ghana in 1976 and as at now more than two hundred (200) rural banks are operating in Ghana (2002 Bank of Ghana Annual Report). The Dangme rural bank which is one of the financial institutions in Ghana and it has six branches with the Prampram branch as its headquarters. The mission of the bank is to be the most viable and efficient rural bank in Ghana. The bank offers services such as saving account and loan schemes etc. The fundamental aim of these rural banks is to help rural communities especially farmers in getting credit facility. The research was conducted to answer the following questions:

a. To what extent is Damgbe Rural Bank aware of the benefits of strategic marketing orientation?

b. How is the impact of strategic marketing on Rural Banks measured?

c. Does strategic marketing affect profitability?

d. Does effective strategic marketing result in managerial efficiency?

\section{Literature Review}

Physical product and core services were what were marketed in the past, but services marketing go beyond that. Services marketing can be seen from four perspectives, services industries and company, service as a product, customer service and derived service and for a very long time only a few publications have been made about services marketing in general and to be specific on the financial services (rural banking) to be precise. The only literature available is centered more on developed countries like United States of America, Britain, Japan, etc. In Ghana, the adoption of the marketing concept is only recent since the clearing Banks have had no real staff competition until recently.

Marketing is the process of planning and executing the conception, placing promotional and distribution of ideas, services to create exchange that satisfy individual and organizational goals (American Marketing Association). Marketing management knowledge and skills is the process of planning and executing, satisfying individual and organizational conception, providing promotional and distribution of ideas, goods and services to create exchange that satisfy individual and organizational objectives (Peter and Donnelly 2003). Phillip Kotler and Gary Armstrong (2010) Global Edition, also define marketing as a social and managerial process by which individuals and groups obtain what they need and want through creating and exchanging value with others. This definition has also been perceived as the most appropriate by some authorities including the governing body of marketing that is the Chartered Institute of Marketing (CIM UK).

According to Clarke et al (1998), financial institutions see or consider marketing moves in a strategic light. Marketing therefore, plays an active role in the formation of corporate strategies. This therefore recognizes 
marketing as very important as marketing decisions are taken at the corporate level. The marketing concept according to Kotler and Keller $10^{\text {th }}$ Edition, posit that "the key of achieving organizational goals consists of determining the needs and satisfaction more effectively and efficiently more than competitors". Effective Strategic marketing is a very key area to improve the overall profitability of rural banks, at this stage it enables the banks to understand and respond to the investment nature or behavior of their customers using such strategies as segmentation (Jagersma, 2003). A strategy is the matching of the activities of the organization to the environment in which it operate and to its own resource capabilities. (Johnson, Scholes and Whittington, 2010).

The essence of developing a marketing strategy for a company is to ensure that the company's capabilities are matched to the competitive market environment in which it operates, not just for today but into the foreseeable future. For a commercial organization such as the Damgbe Rural bank, this means ensuring that its resources and capabilities match the needs and requirement of the market in which it operate. For any strategy to be effective, it needs to be well turned both to the needs and requirements of customers (the market conditions in which it is implemented), and to the resources and capabilities of the firm seeking to implement it. No matter how wonderfully crafted and articulated the strategy, if it is not focused on meeting the needs of customers it is doomed to be a failure.

Similarly, if the organizational (Dangme Rural Bank) resources necessary for its implementation are not available, or cannot be acquired, success will be elusive. Marketing strategy should be set in the context of the overall corporate strategy. Once the overall direction of the bank has been decided, with appropriate input from all relevant stakeholders, the marketing strategy will need to be aligned to ensure that direction is achieved. Once the purpose of the bank has been defined the marketing strategy can be crafted to help achieve that purpose. We can view the development of marketing strategy at three main levels: the establishment of a core strategy, the creation of the company's competitive positioning, and the implementation of the strategy. The Damgbe Rural Bank would achieve profitability with the effective use of strategic marketing. This involves long term strategic goals and objectives that the bank wishes to achieve.

\section{Methodology}

\subsection{The Case Study Strategy}

The literature review indicated that there is insufficient theory and understanding of Strategic marketing within the context of rural banks in Ghana in general and small Ghanaian businesses in particular. A case-study research strategy was adopted to explore the three research questions, using Damgbe Rural Bank in Accra, Ghana as a case. The case-study is one of several ways that research is conducted in the area of social science. A case-study strategy was preferred in this instance because there was a focus on a "contemporary phenomenon within some real-life context" (Yin, 1994, p. 1). Eisenhardt (1989) indicated that the case study is a research strategy which focuses on understanding the dynamics present within single settings and also suggested that case-studies are particularly well suited in areas where existing theory appears inadequate.

\subsection{The Sample}

Because all the customers of Damgbe Rural Bank cannot be contacted, a simple random sampling method was used by the researcher to seek for information. Questionnaires were given to twenty (20) customers and twenty (20) questionnaires given to management and staff. The researcher also decided to use interviews because it has high degree of flexibility, which means it can be easily adjusted to meet many adverse situations. It was also used to help in the verification of responses received from customers and management. Denzin and Lincoln (2000) acknowledge that there are two approaches to a research, qualitative and quantitative. This research adopted a qualitative research. A qualitative research is a descriptive and non-numerical way to collect and interpret information and the researcher is often part of the research being carried out (White, 2009). In small and medium businesses, managers and staff tend to be very conversant with the overall strategies in their organization. Fourteen (15) out of the twenty (20) questionnaires for management and staff were responded to, Five (5) could not avail themselves within the specific time frame. They failed to grant audience and did not respond to the questionnaires as well giving varying reasons. The customers response rate was the same as staff and management .Thus, the sample and response rate was favorable in comparison with other qualitative studies (see for example Omar, 1997 12- respondents; Doherty, 2000 7- respondents; Sen, 2006 7- respondents). In particular, it is considered very high for a study in a developing country like Ghana (Ofori and Hinson, 2007).

\subsection{Data Collection}

The sources of data collection for the purpose of this research work were primary data and secondary data. Customers, management and staff were briefed on the subject matter prior to interviews and their responses to 
the questionnaires, thereby helping to promote validity and reliability through enabling them to gain an understanding of the information being requested. In-depth face to face interviews were found to be suitable, which gave the researcher chance to probe interviewees to uncover underlying reasons for their responses and decisions on Dangme Rural bank. The staff and management of Dangme West Rural Bank, marketing department and other departments were also considered as participants of the research work.

\subsection{Construct Measurement and Data Collection Technique}

The researcher wants to state that for the study under consideration in Accra, it was decided to assess the antecedents of Strategic marketing and whether the practice of strategic marketing has been adopted in the rural banking sector. In this regard, causality was carried out between Strategic marketing practice and performance of Dangme Rural bank. The responses of customers to service quality was used as one of the yardsticks in measuring the implementation of strategic marketing principles. Management admission that the practice of strategic marketing has helped Dangme Rural bank to expand and open six more branches is a measure of the benefits of strategic marketing in the rural banking sector of Ghana.

\section{Presentation and Discussion of Findings}

To deduce sense out of the information that has been collected is always a very difficult task. However, once the data is properly organized and presented valuable information could be extracted from it. The main statistical methods used are tables and pie chart. The researchers visited the head quarters of Damgbe Rural Bank at Prampram with forty (40) questionnaires, twenty (20) for customers and twenty (20) for staff and management of the marketing department. However, we received fifteen questionnaires from the management/staff and fifteen from customers. Their reasons were that some of them forgot to respond because they were too busy whiles others left it at home. Therefore fifteen answered questionnaires from management/staff and fifteen questionnaires from customers were used for the study.

All the respondents said yes which indicates that Damgbe Rural Bank is marketing oriented. This means that the bank held the view that achieving organizational goal depend on determining the need and wants of the target market and delivering the desired satisfaction more effectively and efficiently than competitors. This has been made possible as a result of the existence of a marketing department that sees to the organization's marketing activities.

From the table 2 below, 7 out of $15 \mathrm{staff} /$ management responded yes in relation to whether they are satisfied with the strategic marketing process of the bank which represent $47 \%$. Eight of the staff responded no which represent $53 \%$. This means that some of the staff are satisfied whiles some are not.

Service Quality can be defined as customer's subjective opinions about performances that bring satisfaction or dissatisfaction. It reflects the customer's perception of specific dimensions of service. And the dimensions are Reliability, Responsiveness, Assurance Empathy and Tangibles.

From the analysis made on customers banking with Damgbe Rural bank, it was pointed out clearly that the management of Damgbe Rural bank are meeting service quality demands because the response of customers on the bank's practice of the service dimensions were really high. What we recorded was;

Reliability: Delivery on promise - The bank being able to perform the promised service dependably and accurately.

Responsiveness: Being willing to help - The bank's willingness to help customers and provide prompt service.

Assurance: Inspiring Trust and Confidence - Assurance defined as employee's knowledge and courtesy, and the ability of the firm and its employees to inspire trust and confidence. Damgbe Rural bank's service provider's reputation and credibility and the customer's perceived risk and interrelated.

Empathy: Treating customers as individuals - The caring and individualized attention the bank provides its customers. The essence is to convey to customers that they are unique and special.

Tangibles: Represents service physically - The appearance of physical facilities, equipment, personnel and communications materials. All these provide physical images of the service that customers, especially new ones use to evaluate quality.

All the questions the customers answered can fall under any of service dimensions, although they are probably not equal in importance or performance assessment.

The bank is also seen as customer oriented and has value for customers.

Source: Adapted Service Marketing (Valarie A. Zeithaml, Mary J. Bitner and Dwayne D. Gremler 2009). 


\section{Summary of Findings}

The research work has revealed that, strategic marketing has an impact or effect on profitability. It was also realized that the staff are aware of the benefits of Strategic Marketing

The main aim of the study was to find out if strategic marketing has an effect on profitability in rural bank services. In line with the above, two set of questions were designed for management/staff and customers of Damgbe Rural Bank. After a critical analysis of the data gathered from the survey the researcher came out with the following findings:

Dangme Rural Bank has a marketing department which handles all issues concerning their marketing activities in line with other department in the bank.

The bank has adopted the marketing mix strategy which include promotion, pricing, people, place etc. to make their marketing activities complete.

It was also realized that the strategic marketing process that exist in the bank enables management and staff to take part in decision making and also help in achieving managerial functions (planning, organizing, implementation, evaluation etc). The effective use of strategic marketing has affected the profitability of the bank positively. This has enabled the bank to have six branches in the country. Damgbe rural bank has been achieving their objectives of empowering rural business.

\section{Conclusion}

In conclusion, the research work revealed that strategic marketing has an effect on the profitability of rural banking services. To be specific Damgbe Rural Bank is marketing oriented. Marketing plays a role in the bank by retaining and prospecting for new customers both internal and external. It must be emphasized that, it is through the activities of marketing that has led to the growth and expansion of rural bank in Ghana. It cannot be underestimated that through the activities of rural banks it has led to the mobilization of funds in the rural area. It can now be said that if financial institution are to be successful, they must practice the concept of strategic marketing.

\section{Recommendations}

In spite of the effort of the marketing department of Damgbe Rural Bank, we observed that the bank does not have adequate banking facilities such as Automated Teller Machines (ATM). The study revealed some problems and would like to give the following recommendations. The study showed that the bank's quality service is practical at the same time as commitment therefore we recommend that the staff should pick up on their level of commitment and service quality to help improve profitability and their performance seen to be moderate by their customers. We also recommend that they work on their relationship marketing a little. Although it is clear in the analysis that Damgbe Rural bank is customer oriented, does not mean the perception of their stakeholders especially customers, cannot be changed. We recommend that the bank consistently meet or exceed customer expectations to overcome most of the major problems unique in services. Furthermore it will be essential for Damgbe Rural bank to embrace continuous service quality improvements or accelerate business improvements. This is essential because customers' needs do and are constantly changing.

Strategic marketing is also about Ethical codes. We recommend that Damgbe Rural bank, should not just consider the profitability aspect of the bank but the moral aspect as well. In that the customer's purpose frequent deposit or withdrawal should or must be questioned and advised on when necessary and their source of resource should be questioned. They should demonstrate goodwill to customers so they can feel acknowledged and valued and somehow work on their ambiance.

\section{References}

Bank of Ghana Annual Report. (2002).

Doherty, A.M. (2000). Factors influencing international retailers market entry mode strategy: qualitative evidence from the UK fashion sector. Journal of Marketing Management, 16 (1/3), 223-45. http://dx.doi.org/10.1362/026725700785100514

Eisenhardt, K. (1989). Building Theories from Case Study Research. Academy of Management Review, 14 (4), 532-550.

FAO. (1994). Rural Poverty in the 1990s. Rural Development Special, No. 15. Ghana Universities Press, Accra, Ghana 
Moshi Conference. (1969). The African Regional Conference on the Integrated Approach to Rural Development, held in Moshi, Tanzania.

Ofori, D. F., and Hinson, R. E. (2007). Corporate Social Responsibility (CSR) Perspectives of Leading Firms in Ghana. Corporate Governance, 7, (2), 178-193. http://dx.doi.org/10.1108/14720700710739813

Omar, O.E. (1997). Target pricing: a marketing management tool for pricing new cars. Pricing Strategy and Practice, 5 (2), 61-9. http://dx.doi.org/10.1108/09684909710163610

Sen., B. (2006). Defining market orientation for libraries. Library Management, 27 (4/5), 201-217. http://dx.doi.org/10.1108/01435120610668151

Jagersma. (2003). Yahoo search.

P. Kotler and Keller. (2009). Marketing Management (13 ${ }^{\text {th }}$ Edition). Prentice Hall.

Peter and Donnelly. (2003). Marketing Management Knowledge and Skills (10 ${ }^{\text {th }}$ Edition). Pg.247.

P. Kotler and G. Armstrong. (2010). Principles of Marketing (13 ${ }^{\text {th }}$ Global Edition). Pearson.

Cannon. (1998). Marketing Principles and Practice. Yahoo search.

Johnson, Scholes and Whittington. (2010). Strategic Marketing ( $6^{\text {th }}$ Edition).

Kudiabor, C.D.K. (1974). Policy Objectives and Strategies for Integrated Rural Development in Ghana. Rural Development in Ghana. Ghana Universities Press, Accra, Ghana, 26-32.

K. Baku. (2001). Fundamentals of Marketing, Pg.7.

G. Hooley, J. Saunders and N. Piercy. (2004). Marketing Strategy and Competitive Positioning (3 ${ }^{\text {rd }}$ Edition). Prentice Hall. Pg.17.

Survey Data of Management. (2011). Microsoft Excel.

Survey Data of Customers. (2011). Statistical Package for Social Sciences (SPSS).

V. A. Zeithaml, M.J. Bitner and D.D. Gremler. (2009). Service Marketing; Integrating Customer Focus Across the Firm. (5 ${ }^{\text {th }}$ McGraw - Hill International Edition). Pg.111.

Yin, R. K. (1994). Case Study Research - Design and Methods (2nd ed.). Thousand Oaks, CA, Sage Publications.

Table 1. Response on whether Damgbe rural bank is marketing oriented

\begin{tabular}{|c|c|}
\hline Response & Number of Response \\
\hline Yes & 15 \\
\hline No & 0 \\
\hline Total & 15 \\
\hline
\end{tabular}

Source: Survey Data (2011)

Table 2. Response on whether management/staff is satisfied with the strategic marketing process of the bank

\begin{tabular}{|c|c|}
\hline Response & Number of Response \\
\hline Yes & 7 \\
\hline No & 8 \\
\hline Total & 15 \\
\hline
\end{tabular}

Source: Survey Data (2011) 
Table 3. Customers' response on whether strategic marketing has an impact on the company's profitability

\begin{tabular}{|c|c|}
\hline Response & Number of response \\
\hline Strongly agree & 7 \\
\hline Agree & 4 \\
\hline Disagree & 4 \\
\hline Strongly disagree & 0 \\
\hline Total & 15 \\
\hline
\end{tabular}

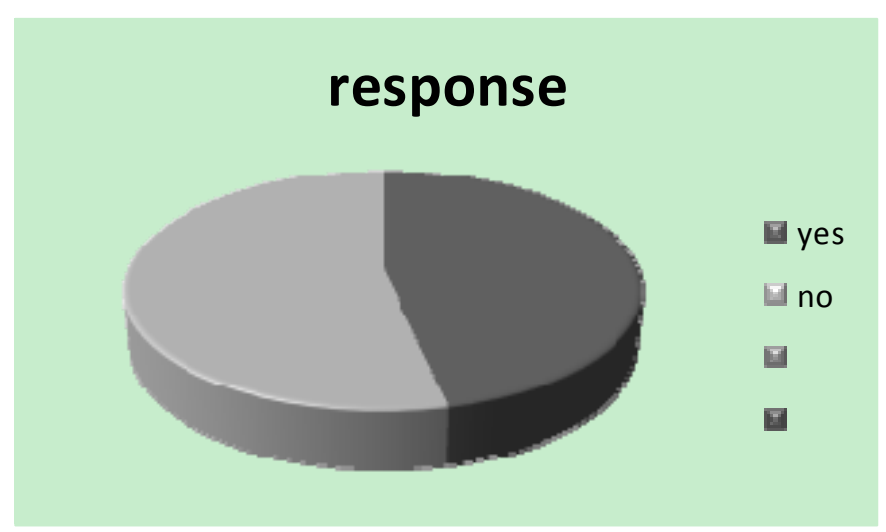

Figure 1. Response on whether management/staff is satisfied with the strategic marketing process of the bank

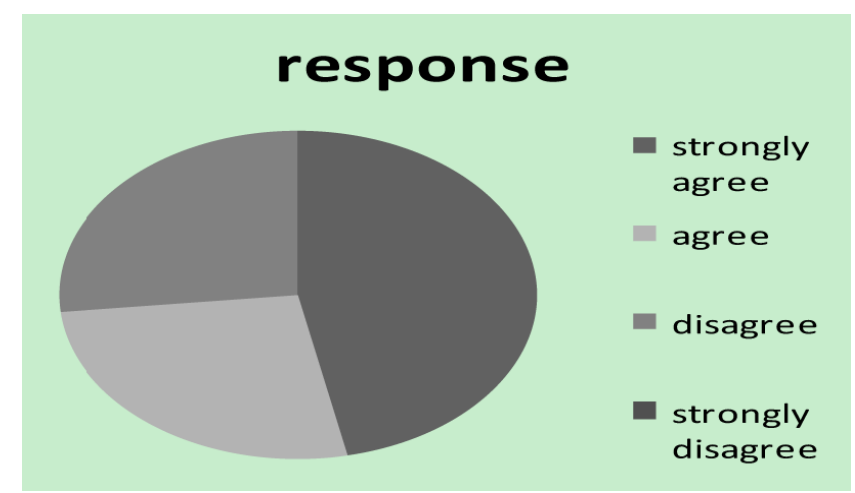

Figure 2. Customers' response on whether strategic marketing has an impact on the company's profitability 